\title{
Productivity of Potato (Solanum tuberosum L.) as Influenced by Calcium Metalosate
}

\author{
R. Jayaramaiah, G. Pramod and B. T. Naveen Kumar* \\ Department of Agronomy, College of Agriculture, Karekere, Hassan, Karnataka, India \\ *Corresponding author
}

Keywords

Calcium

Metalosate, Growth,

Late blight, Tuber number and Yield

Article Info

Accepted:

28 February 2018

Available Online:

10 March 2018

\section{A B S T R A C T}

Field trail was carried out at the farm unit, College of Agriculture, Hassan Karnataka during the year 2015 to study the effect of foliar application of calcium metalosate on growth, yield and quality parameters of potato. The experiment consisted of 7 treatments viz., $\mathrm{T}_{1}$ : Control, $\mathrm{T}_{2}$ : Calcium metalosate @ $1 \mathrm{ml} / \mathrm{l}, \mathrm{T}_{3}$ : Calcium metalosate @ $2 \mathrm{ml} / \mathrm{l}, \mathrm{T}_{4}$ : Calcium metalosate @ $3 \mathrm{ml} / \mathrm{l}, \mathrm{T}_{5}$ : Calcium metalosate @ $4 \mathrm{ml} / \mathrm{l}, \mathrm{T}_{6}$ : Calmagni @ $2 \mathrm{~g} / \mathrm{l}$ and $\mathrm{T}_{7}$ : Samras (amino acid mixture) @ $2 \mathrm{ml}$. The experiment was laid out in randomized complete block design and replicated thrice. Application of calcium metalosate at different concentration had significant influence on productivity of potato. At harvest, application of calcium metalosate @ $4 \mathrm{ml} / 1\left(\mathrm{~T}_{5}\right)$ recorded significantly higher plant height $(66.57 \mathrm{~cm})$, more number of leaves (15.33), number of shoots (3.51) at 60 DAP, total dry matter production (52.13 $\left.\mathrm{g} \mathrm{plant}^{-1}\right)$, less number of days to $50 \%$ flowering (60 days), number of tubers $\left(6.53 \mathrm{~g} \mathrm{plant}^{-1}\right)$, yield $\left(263.29 \mathrm{~g} \mathrm{plant}^{-1}\right)$ and total yield $\left(22.54 \mathrm{t} \mathrm{ha}^{-1}\right)$ as compared to control $\left(\mathrm{T}_{1}\right)$ which was on par with calcium metalosate @ $3 \mathrm{ml} / 1\left(\mathrm{~T}_{4}\right)$. Same treatment significantly reduced the late blight severity at $60 \mathrm{DAP}(19.10 \%)$ and weight reduction 30 days after harvest $(10.10 \%)$.

\section{Introduction}

Potato (Solanum tuberosum L.) belongs to the genus solanum. All cultivated species have been grouped under the series tuberose of sub section potatae. About $72 \%$ of the species are diploid $(2 n=48)$. The rest are triploid $(2 n=36)$, pentaploid $(2 n=66)$ and hexaploid $(2 n=72)$. The widely cultivated potato belongs to tetraploid species Solanum tuberosum L. Potato is one of the most important food crop of the world. This is next to rice, wheat and maize. Potato is the only crop which could supplement the need of food of the country. It is a potential crop which can be harvested and the tuber can be consumed any time after 60 days of planting. The potato contains all major nutrients like proteins, vitamins, calcium, phosphorus and is treasure house of carbohydrates which are essential for the body building. The production potential of potato per unit area and per unit time is higher than most of field crops. So the problems of under and malnutrition can largely be solved if potato is accepted as a major food and not merely as a vegetable in our country. The 
potato is a crop which has always been "Poor man's friend" Because potatoes contain large quantity of starch. It is also called as "King of vegetables" because it has huge nutritive value (Per 100 gram of edible matter) mainly moisture (74.7 \%), protein $(1.6 \mathrm{~g})$, carbohydrates $(22.6 \mathrm{~g})$, minerals $(0.6 \mathrm{~g})$, fibre $(0.4 \mathrm{~g})$, calcium $(10.0 \mathrm{~g})$, vitamin A (40 IU) and Vitamin C (17 IU).

The potato is of American origin and has been cultivated in northern Chile and Peru. It was cultivated probably by Portuguese who brought the potato into India. The USSR, China, Poland, India and USA are leading countries in area and production of potato in the world. India stands fourth in area and fifth in production. Potato is cultivated as a versatile crop and can be grown under diverse range of agro-climatic condition. It is a crop of temperate climate and thrives well in cool climate $\left(15.5{ }^{0} \mathrm{C}\right.$ to $\left.21.1{ }^{\circ} \mathrm{C}\right)$. It is cultivated as rainfed crop as well as irrigated crop. High rainfall and humidity are detrimental to this crop. Soil moisture stress results in lower yield of potato. The temperature exercises a marked influence on plant growth and tuber development. Tuberisation is best at $17.7^{\circ} \mathrm{C}$ and maximum tuber production is takes place at $20{ }^{\circ} \mathrm{C}$. Crop can be grown in all types of soil except alkaline soil and soil with higher clay content. Sandy loam, loamy soil and sandy soil rich in organic matter are most suitable for potato cultivation. The area, production, productivity of the World is 19.5 million ha, 321 million tonnes, $19.8 \mathrm{t} \mathrm{ha}^{-1}$ respectively and of India is 20.63 lakh ha, 455.69 lakh million tones and $22.02 \mathrm{t} \mathrm{ha}^{-1}$ respectively. Area of Karnataka is 48,000 ha and production is 6.52 million tones and productivity $14 \mathrm{t} \mathrm{ha}^{-1}$, respectively.

There is scope to enhance the productivity of potato crop by proper agronomic practices like use of proper dosage of fertilizers and at recommended time, disease management etc.
Symptoms of micronutrient deficiencies clearly appear on cultivated plants in Karnataka soil because most of these soils are poor in secondary nutrients especially calcium and with low content of organic matter, all these factors lead to a shortage of readiness of micronutrients. Despite the presence in the soil quantities outweigh the need for the plant (Saleh, 2010), The most vegetable crops grown in these conditions suffer from micronutrient deficiencies and there are a clear respons to spray nutrients (Al -Mohammadi, 2005). Kohraee et al., (2011) explained that calcium is essential material for growth and used in small quantities compared to the major nutrients $\mathrm{N}, \mathrm{P}, \mathrm{K}$ and they play an important role in cells division and development, metabolism, respiration increased maturity speed. Alloway (2004) pointed that the use of fertilizers containing calcium element lead to increasing the quantity and improving the quality of potato tubers when calcium activates enzymes and the representation of carbohydrates and proteins manufacturing. Keeping the above points in view, the field trail was conducted to study the response of potato to foliar application of calcium metalosate on growth, yield and quality parameters.

\section{Materials and Methods}

The trail was carried out at the farm unit, College of Agriculture, Hassan, which comes under southern Transition Zone (Zone -7) of Karnataka during 2015 on red sandy loam soil with neutral $\mathrm{pH}$ (7.1), low soil organic carbon $(0.51 \%)$, medium available $\mathrm{N}\left(345.3 \mathrm{~kg} \mathrm{ha}^{-1}\right)$, high available $\mathrm{P}_{2} \mathrm{O}_{5}\left(54.8 \mathrm{~kg} \mathrm{ha}^{-1}\right)$, medium available $\mathrm{K}_{2} \mathrm{O}\left(230.0 \mathrm{~kg} \mathrm{ha}^{-1}\right)$ and low in available calcium (1.25 meq/ $100 \mathrm{~g})$. This is situated at latitude of $12^{\circ} 13^{\prime} \mathrm{N}$ and $13^{0} 33^{\prime} \mathrm{N}$ latitude and $75^{\circ} 33^{\prime}$ and $76^{\circ} 38^{\prime} \mathrm{E}$ longitude at an altitude of $827 \mathrm{~m}$ above mean sea level (MSL). Normal climatic conditions were prevailing during experimental period. The 
total rainfall received was $384 \mathrm{~mm}$ during the crop season. The average maximum temperature of $33{ }^{0} \mathrm{C}$ in the month of May 2015 and the average minimum of $13{ }^{0} \mathrm{C}$ during the month of December 2015 was recorded. The mean monthly relative humidity ranged from $83 \%$ in May - June to $86 \%$ in July - August. Overall weather condition prevailed during crop growing period was very good and thus, helped to get good crop stand and optimum yield.

The experiment consisted of 7 treatments viz., $\mathrm{T}_{1}$ : Control, $\mathrm{T}_{2}$ : Calcium metalosate @ $1 \mathrm{ml} / \mathrm{l}$, $\mathrm{T}_{3}$ : Calcium metalosate @ $2 \mathrm{ml} / \mathrm{l}, \mathrm{T}_{4}$ : Calcium metalosate@3 ml/1, T5: Calcium metalosate @ $4 \mathrm{ml} / 1, \mathrm{~T}_{6}$ : Calmagni @ $2 \mathrm{~g} / \mathrm{l}$ and $\mathrm{T}_{7}$ : Samras (amino acid mixture) @ $2 \mathrm{ml}$. The experiment was laid out in randomized complete block design and replicated thrice. A potato var. Kufri jyothi was used for experimentation.

The land was ploughed twice by tractor drawn mould board plough and cultivator after harvest of previous crop and on receipt of shower on June $2^{\text {nd }} 2015$. After harrowing, the land was smoothened with wooden plank. All the plots were dug manually and clods were crushed and leveled.

The plots were demarcated as per layout and bunds were raised around each plot. The recommended dose of $\mathrm{N}: \mathrm{P}_{2} \mathrm{O}_{5}: \mathrm{K}_{2} \mathrm{O}$, 125:100:125 kg/ha was applied as per the recommendation and $25 \mathrm{t} \mathrm{ha}^{-1}$ of FYM was applied and incorporated three weeks in advance. Hand weeding fallowed by harrowing at 25 days after planting and earthing up was done using plough @ 35 days after planting.

Micronutrient mixtures like Calcium Metalosate, Calmagni and Samras were sprayed at given concentration at 30 DAP $\left(\right.$ July $\left.5^{\text {th }} 2015\right), 45$ DAP ((July $\left.20^{\text {th }} 2015\right)$, and
60 DAP (August 05 ${ }^{\text {th }}$ 2015). The crop was given one spray of Dithane M-45 @3g/l and Imidacloprid@2ml/1@30 DAP. Another spray of Moximate @ 3g/l and Monocrotophos was given@2ml/1@45DAP another spray of $\lambda$-Cyhalothrin and $\mathrm{Matco}^{+} @$ 60DAP. Crop was harvested at 90 DAP when the foliage turned yellowish brown and started drying. The plants were uprooted by digging carefully without damaging the tubers from the net plots.

Five potato representative plants were sampled at harvest to record growth and yield comparatively and harvesting of potato was done from the net plot for computing tuber yield $\mathrm{ha}^{-1}$. The data obtained from various studies were statistically analyzed following the procedure as described by Gomez and Gomez (1984).

\section{Results and Discussion}

\section{Growth parameters}

Application of calcium metalosateat different growth stages had significant influence on growth parameters over control. At harvest, among all the treatments, calcium metalosate @ $4 \mathrm{ml} / \mathrm{l}\left(\mathrm{T}_{5}\right)$ recorded significantly higher plant height $(66.57 \mathrm{~cm})$, more number of leaves (15.33), number of shoots (3.51) at 60 DAP, total dry matter production $(52.13 \mathrm{~g}$ plant $^{-1}$ ) and less number of days to $50 \%$ flowering (60 days) as compared to control (54.66 cm, 4.36, 2.92, $41.68 \mathrm{~g} \mathrm{plant}^{-1}$ and 62 days, respectively). However, it was on par with calcium metalosate @ $3 \mathrm{ml} / 1(65.21 \mathrm{~cm}$, 14.77, 3.40, 52.08 $\mathrm{g} \mathrm{plant}^{-1}$ and 60.33 days, respectively) (Table 1). This could be due to the compound effects of many factors, namely additional nutrient, improved soil physical properties, water regimes, better water extraction, aeration and resource use rather than conventional tillage (Unger and Jones, 1998). 
Table.1 Growth parameters of potato at harvest as influenced by application of various levels of calcium metalosate

\begin{tabular}{|c|c|c|c|c|c|}
\hline Treatments & $\begin{array}{l}\text { Plant } \\
\text { height } \\
\text { (cm) }\end{array}$ & $\begin{array}{l}\text { Number } \\
\text { of leaves }\end{array}$ & $\begin{array}{c}\text { No. of } \\
\text { Shoots/plant } \\
\text { (60 DAP) }\end{array}$ & $\begin{array}{l}\text { Total dry } \\
\left.\text { matter }^{-1} \text { (g plant }{ }^{-1}\right)\end{array}$ & $\begin{array}{c}\text { Days to } \\
\mathbf{5 0 \%} \\
\text { flowering }\end{array}$ \\
\hline $\mathrm{T}_{1}:$ Control & 54.66 & 4.36 & 2.92 & 41.68 & 62.00 \\
\hline $\mathrm{T}_{2}:$ Calcium metalosate @ $1 \mathrm{ml} / \mathrm{l}$ & 59.62 & 5.67 & 3.33 & 42.61 & 61.87 \\
\hline $\mathrm{T}_{3}$ : Calcium metalosate @ $2 \mathrm{ml} / \mathrm{l}$ & 64.75 & 14.33 & 3.33 & 47.47 & 61.67 \\
\hline $\mathrm{T}_{4}$ : Calcium metalosate @ $3 \mathrm{ml} / \mathrm{l}$ & 65.21 & 14.77 & 3.40 & 52.08 & 60.33 \\
\hline $\mathrm{T}_{5}:$ Calcium metalosate @ $4 \mathrm{ml} / \mathrm{l}$ & 66.57 & 15.33 & 3.51 & 52.13 & 60.00 \\
\hline $\mathrm{T}_{6}:$ Calmagni @ 1g/l & 55.45 & 7.33 & 3.37 & 44.66 & 61.33 \\
\hline $\mathrm{T}_{7}:$ Samras @ $2 \mathrm{ml} / \mathrm{l}$ & 53.93 & 6.85 & 3.18 & 41.72 & 60.67 \\
\hline S.Em \pm & 2.73 & 0.92 & 0.36 & 2.36 & 0.40 \\
\hline $\mathrm{CD}(\mathrm{p}=0.05)$ & 8.28 & 2.80 & 1.08 & 7.16 & 1.22 \\
\hline
\end{tabular}

Table.2 Yield parameters of potato at harvest as influenced by application of various levels of calcium metalosate

\begin{tabular}{|c|c|c|c|c|c|c|}
\hline \multirow[t]{2}{*}{ Treatments } & \multirow{2}{*}{$\begin{array}{l}\text { No. of } \\
\text { tubers } \\
\text { Plant }^{-1}\end{array}$} & \multirow{2}{*}{$\begin{array}{c}\text { Tuber } \\
\text { yield } \\
\left(\text { g plant }^{-1}\right)\end{array}$} & \multicolumn{3}{|c|}{ Tuber grading ( ha $\left.^{-1}\right)$} & \multirow{2}{*}{$\begin{array}{l}\text { Total } \\
\text { yield } \\
\text { t ha }^{-1}\end{array}$} \\
\hline & & & $\underset{<25 g}{A}$ & $\begin{array}{c}\text { B } \\
25-100 \mathrm{~g}\end{array}$ & $\begin{array}{c}C \\
>100 g\end{array}$ & \\
\hline $\mathrm{T}_{1}:$ Control & 5.23 & 210.49 & 5.13 & 8.64 & 3.40 & 17.28 \\
\hline $\mathrm{T}_{2}:$ Calcium metalosate @ $1 \mathrm{ml} / \mathrm{l}$ & 5.73 & 215.21 & 5.37 & 8.97 & 3.60 & 17.94 \\
\hline $\mathrm{T}_{3}$ : Calcium metalosate @ $2 \mathrm{ml} / \mathrm{l}$ & 6.03 & 239.77 & 6.52 & 9.99 & 3.47 & 19.98 \\
\hline T4: Calcium metalosate @ $3 \mathrm{ml} / \mathrm{l}$ & 6.36 & 263.01 & 7.15 & 11.11 & 3.66 & 21.92 \\
\hline $\mathrm{T}_{5}$ : Calcium metalosate @ $4 \mathrm{ml} / \mathrm{l}$ & 6.53 & 263.29 & 7.41 & 11.37 & 3.76 & 22.54 \\
\hline $\mathrm{T}_{6}:$ Calmagni @ 1g/l & 6.23 & 225.57 & 5.52 & 9.65 & 3.63 & 18.80 \\
\hline T7:Samras@ $2 \mathrm{ml} / \mathrm{l}$ & 5.40 & 207.37 & 5.16 & 8.77 & 3.44 & 17.54 \\
\hline S.Em & 0.23 & 11.92 & 0.46 & 0.51 & 0.11 & 0.99 \\
\hline$C D(p=0.05)$ & 0.69 & 36.15 & 1.41 & 1.55 & 0.33 & 3.01 \\
\hline
\end{tabular}

Table.3 Disease incidence and weight reduction as influenced by application of various levels of calcium metalosate

\begin{tabular}{|c|}
\hline Treatments \\
\hline $\mathrm{T}_{1}:$ Control \\
\hline $\mathrm{T}_{2}$ : Calcium metalosate @ $1 \mathrm{ml} / \mathrm{l}$ \\
\hline $\mathrm{T}_{3}$ : Calcium metalosate @ $2 \mathrm{ml} / \mathrm{l}$ \\
\hline $\mathrm{T}_{4}$ : Calcium metalosate @ $3 \mathrm{ml} / \mathrm{l}$ \\
\hline $\mathrm{T}_{5}:$ Calcium metalosate @ $4 \mathrm{ml} / \mathrm{l}$ \\
\hline $\mathrm{T}_{6}:$ Calmagni @ 1g/1 \\
\hline $\mathrm{T}_{7}:$ Samras @ $2 \mathrm{ml} / \mathrm{l}$ \\
\hline S. Em \pm \\
\hline
\end{tabular}

\begin{tabular}{|c|c|c|}
\hline \multicolumn{2}{|c|}{ Late blight Severity (\%) } & $\begin{array}{c}\text { Weight reduction in \% } \\
\text { (30 days after harvest) }\end{array}$ \\
\hline 24.12 & 54.85 & 13.02 \\
\hline 23.41 & 54.53 & 12.05 \\
\hline 20.78 & 42.63 & 11.48 \\
\hline 20.10 & 42.52 & 10.18 \\
\hline 19.10 & 42.72 & 10.10 \\
\hline 22.15 & 42.67 & 10.57 \\
\hline 21.10 & 44.25 & 11.82 \\
\hline 1.01 & 2.59 & 0.14 \\
\hline 3.07 & 7.86 & 0.42 \\
\hline
\end{tabular}


This might be due to optimum availability of nutrients through foliar application of mineral mixture at appropriate growth stage which enhanced rate of photosynthesis and consequently led to better vegetative growth. Increase in dry matter production of tubers occurred at harvest indicating that photosynthates were effectively translocated from haulms to tubers. Increased dry matter in tubers may be attributed to increased leaf area and consequent increase in production of photosynthates and better root growth and spread due to the application of mineral mixture which helped in increasing absorption of nutrients and also translocation of photosynthates to tubers. Similar results were concurred with Krishnamurthy et al., (2002) and Ali et al., (2013).

\section{Yield and yield attributing parameters}

Crop growth and productivity are influenced by both external and internal factors. Nutrient management is one such important factor. The yield parameters of potato varied significantly due to application of various levels of calcium metalosate. The higher number of tubers per plant, tuber yield per plant and total yield (6.53, 263.29 $\mathrm{g}$ and $22.54 \mathrm{tha}^{-1}$, respectively) were recorded with foliar application of calcium metalosate@ $4 \mathrm{ml} / \mathrm{l}\left(\mathrm{T}_{5}\right)$ which was on par with calcium metalosate @ $3 \mathrm{ml} / \mathrm{l}\left(\mathrm{T}_{4}\right.$, 6.36, 263.01 $\mathrm{g}$ and $21.92 \mathrm{t} \mathrm{ha}^{-1}$, respectively) and these parameters were lower with control $\left(\mathrm{T}_{1}, \quad 5.23,210.49 \mathrm{~g}\right.$ and $\left.17.28 \mathrm{t} \mathrm{ha}^{-1}\right)$ respectively (Table 2). Tuber grading at harvest also followed the same trend. This may be attributed to higher uptake of nutrients as a result of which the foliage cover was more and led to higher dry matter production per plant due to the added nutrients through foliar application of micro nutrients. And foliar application of micronutrients increases the physiological process and cell division and elongation which indirectly influence tissue formation and consequently vegetative growth of plant. Similar trend was observed by Sharma et al., (2010).

\section{Disease incidence}

The late blight severity @ 60 DAP and 75 DAP and weight reduction in \% $30 \mathrm{DAH}$ of potato varied significantly due to application of various levels of calcium metalosate. The lower late blight incidence @ 60 DAP and 75 DAP and weight reduction in \% $30 \mathrm{DAH}$ (19.10\%, 42.72\% \& 10.10\%) were recorded with calcium metalosate @ 4 ml/l $\left(\mathrm{T}_{5}\right)$ which was on par with calcium metalosate@ $3 \mathrm{ml} / \mathrm{l}$ (20.10\%, 42.52\% \& 10.18\%), respectively and these parameters were lower with control $\left(\mathrm{T}_{1}, 24.12 \%, 54.85 \% \& 13.02 \%\right)$ respectively (Table 3). This might be due to supplied calcium enhanced the cell division and cell elongation which reduced the late blight disease incidence.

\section{Acknowledgment}

The authors acknowledge the Indofil Industries Limited for providing funds to conduct experiment at best level and Assistant Professors, Department of Agronomy extending the help to conduct the experiment systematically.

\section{References}

AL- Mohammadi, H. Sh. Sharqi. 2005. Effect of Foliar application of $\mathrm{Zn}$ and $\mathrm{Fe}$ on growth and yield of Sorghum bicolori Moench. Msc. Thesis, College of Agric. Univ. of AL- Anbar University. AL. Farhan, H. N. 2001. Potato Physiology, Awan for information Services, Sanaa, Yemen.

Ali, J., Hussein, M. J. and Makki, N.N., 2013, Effect of foliar application on growth and yield of seven cultivars of potato, Euphrates Journal of Agricultural Sciences, 5(1):1-7. 
Alloway, B. J., 2004. Calcium in soil and crop nutrition International Zinc Association (IZA). www. Zincworld. Org.

Gomez, K. A. and A. A. Gomez. 1984, Statistical Procedures for Agricultural Research, An international Rice Research Institute Book, Wiley- Inter Science Publication, New York, USA, p. 680 .

Kohraee, A. Heydari M, Tavassoli A. 2011. The effect of planting date and source of tubers on the quality of potato tubers in autumn and spring. American Journal of Potato Research, 83:195-206.

Krishnamurthy, N., Abdul Khalak, G.M., Sujith, h. K. and Shivaraj, B., 2002,
Integrated nutrient supply and management for potato production in alfisols. Potato Global Research and Development, 2: 85-856.

Saleh, Hammed M., 2010. Effect of foliar application of some micronutrient on grain yield of wheat (Triticum aestium) and some of its components. Journal of Tikrit University of Agricultural Sciences, 10(2): 129- 137.

Sharma, R. C., Trehan, S. P. and Roy, S. K., 2010. Potato variety differences in nutrient deficiency symptoms and responses to NPK. Better Crops International, 15 (1): 18-21.

\section{How to cite this article:}

Jayaramaiah R., G. Pramod and Naveen Kumar B. T. 2018. Productivity of Potato (Solanum tuberosum L.) as Influenced by Calcium Metalosate. Int.J.Curr.Microbiol.App.Sci. 7(07): 4208-4213. doi: https://doi.org/10.20546/ijcmas.2018.707.492 